\title{
Optimization of Water Fraction Gel Formula of Binahong Leaf (Anredera cordifolia (Ten.) Steen) With Gelling Agent of Sodium Alginate and Carboxymethyl Chitosan Combination
}

\author{
Citra Ariani Edityaningrum, Kintoko*, Feby Zulien, Lina Widiyastuti \\ Ahmad Dahlan University, Yogyakarta
}

\begin{abstract}
Water fraction of binahong (Anredera cordifolia (Ten.) Steen) leaf has been proven to heal ulcus diabetic. In order to make the use easier and more practical, in this study the water fraction of binahong leaves is formulated in gel preparation form. This study was conducted to obtain a comparison of the amount of sodium alginate and carboxymethyl chitosan as gelling agent to produce gel that meets the good physical requirements. The method used to determine the amount of comparison of sodium alginate and carboxymethyl chitosan is to use Simplex Lattice Design (SLD). Eight variations of gel formula are designed with the ratio of sodium alginate: carboxymethyl chitosan as follows: F1 (0:3\% w/w), F2 (0:3\% w/w), F3

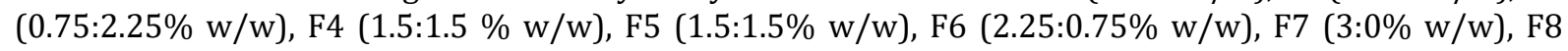
$(3: 0 \% \mathrm{w} / \mathrm{w})$. Physical parameters observed included $\mathrm{pH}$, viscosity, dispersion, and adherence. Data obtained compared with the actual conducted by researchers using one sample test t-test with $95 \%$ confidence level. Based on the results of the study, increased sodium alginate concentration can increase viscosity and adhesiveness and decrease the $\mathrm{pH}$ and spreadability of the gel. One sample t-test analysis shows that there is no significant difference between predicted parameter value and actual result so SLD equation can be used to construct gel formula of water fraction of binahong leaf. The conclusion is a combination of sodium alginate $1.546 \% \mathrm{w} / \mathrm{w}$ and carboxymethyl chitosan $1.454 \% \mathrm{w} / \mathrm{w}$ yield gel optimum. Physical parameter response of optimum formula is pH 5.86; viscosity $2000 \mathrm{cps}$; spreadability of $21,96 \mathrm{~cm}^{2}$; and adhesiveness of 19,81 seconds.
\end{abstract}

Key words: gel; water fraction of binahong leaf; sodium alginate; carboxymethil chitosan

\section{INTRODUCTION}

Herbal medicines in therapy has been widely used by Indonesian people. This is because Indonesia is very rich in germplasm resources as raw material for medicines, one of them is binahong/heartleaf (Anredera cordifolia (Ten.) Steen) from the family of Basellaceae (Vivian-Smith, 2007). Binahong leaves can be used to cure various types of wounds including burns, incisions, and wounds from diabetes mellitus (Laissa et al., 2017; Eriadi et al., 2015; Kintoko et al., 2017). The efficacy of binahong leaf is scientifically proven by research conducted by Kintoko et al., (2017) which shows that the water fraction (10\%) of binahong leaves has been proven to cure the wounds of diabetes mellitus by $69.34 \%$ in 10 days.

The use of the binahong leaf water fraction directly on the injured skin is less practical and comfortable, so it needs to be formulated in preparations. The preparation chosen is gel form.

\section{*Corresponding author : Kintoko}

Email : kkintoko77@gmail.com
Gel is a semi solid transparent or translucent preparation solutions of one or more active ingredients dispersed on an appropriate basis (Lund, 2009). High water content in the gel base can also function as a penetration enhancer with a hydration mechanism in the stratum corneum layer so that it will increase delivery for both hydrophilic and lipophilic drugs (Mahanani, 2009). Therefore, gel is one of a promising type of topical preparation.

To produce gels for water-soluble fraction of binahong water, polymers with good solubility in water are needed to form a homogeneous gel mass. Natural sodium alginate and carboxymethyl chitosan polymers have a good water solubility and can forma thick colloidal dispersions (Rowe et al., 2009; Xue et al., 2009). In addition, both of them are having low toxicity, biocompatible, and biodegradable (Xue et al., 2009; Kartika et al., 2015). Sodium alginate has a high viscosity which will be good when combined with carboxymethyl chitosan which has low viscosity so that it can produce a gel with a good target gel viscosity of 
Table I. Gel Binahong Leaf Water Fraction Formula

\begin{tabular}{lcccccccc}
\hline \multicolumn{1}{c}{ Materials } & F1 & F2 & F3 & F4 & F5 & F6 & F7 & F8 \\
\hline Binahong leaf water fraction & 10 & 10 & 10 & 10 & 10 & 10 & 10 & 10 \\
Sodium alginate & 0 & 0 & 0.75 & 1.5 & 1.5 & 2.25 & 3 & 3 \\
Carboxymethyl chitosan & 3 & 3 & 2.25 & 1.5 & 1.5 & 0.75 & 0 & 0 \\
Methyl paraben & 0.2 & 0.2 & 0.2 & 0.2 & 0.2 & 0.2 & 0.2 & 0.2 \\
Propyl paraben & 0.005 & 0.005 & 0.005 & 0.005 & 0.005 & 0.005 & 0.005 & 0.005 \\
Glycerin & 5 & 5 & 5 & 5 & 5 & 5 & 5 & 5 \\
Propylene glycol & 15 & 15 & 15 & 15 & 15 & 15 & 15 & 15 \\
Distilled water up to & 100 & 100 & 100 & 100 & 100 & 100 & 100 & 100 \\
\hline
\end{tabular}

2000-4000 cps (Garg et al., 2002) so that it is easy to apply. The concentration range is chosen from 0 $3 \%$ based on the orientation that sodium alginate at a concentration of $3 \%$ has already produced a thick gel. The determination of the amount of sodium alginate and carboxymethyl chitosanin this study is using Simplex Lattice Design.

\section{METHODOLOGY \\ Materials}

Binahong leaf water fraction powder used in this study is come from the research by Kintoko et al., (2017). Other ingredients include sodium alginate (Wako Pure Chemical Industries, Ltd.), carboxymethyl chitosan, glycerin (Bratachem), propylene glycol (Bratachem), methyl paraben (Bratachem), propyl paraben (Bratachem), and distilled water.

\section{Tools}

The tools used in this study include mixer (EMV), pH meter (Lutron PH-208), viscometer (Rheosys Merlin VR), spreadability test equipment, and adhesiveness test equipment.

\section{Production of Binahong Leaf Fraction Dry Powder}

The dry binahong leaf simplicia is mashed up and sifted with 14 mesh. $500 \mathrm{~g}$ of the sample is weighed and then extracted with $96 \%$ ethanol as much as $5 \mathrm{~L}$ for 24 hours. The extraction is carried out gradually 3 times. Macerate is filtered then evaporated, and yawned using a water bath at temperature $60{ }^{\circ} \mathrm{C}$. Fractionation is carried out on thick extract obtained by adding $1 \mathrm{~L}$ of aquadest. Then the mixture is centrifuged at $4000 \mathrm{rpm}$ for 15 minutes. The supernatant obtained is then filtered and evaporated using a freeze dryer until dry powder is obtained (Kintoko et al., 2017).

\section{Production of Binahong Leaves Fraction Gel Formula}

Variations in the amount of gelling agent sodium alginate and carboxymethyl chitosan is in the range $0-3 \% \mathrm{w} / \mathrm{w}$ designed by using Software Design Expert 11 Simplex Lattice Design method. The amount of each component (Table I). The production of the gel begins by mixing sodium alginate and carboxymethyl chitosan each with a part of water until it expands, then stirred using a mixer until a clear mass is formed. A number of methyl parabens and propyl parabens (Table I) are dissolved in the propylene glycol, then glycerin is added, and stirred until homogeneous. Those ingredients are inserted into the gelling agent and stirred until homogeneous. The binahong leaf water fraction is dissolved in the remaining water, then put into the gel gradually while stirring to form a homogeneous gel mass.

\section{Gel Physical Properties Test}

Organoleptic Observation

Organoleptic observations of gel preparation include visual form, color and odor (Swastika et al., 2013).

\section{PH measurement}

$\mathrm{PH}$ observation is conducted using a $\mathrm{pH}$ meter. Electrode is dipped in the container, and left until the numbers move to a constant position. The number shown by the $\mathrm{pH}$ meter is the $\mathrm{pH}$ value of the dosage (Shanti and Mita, 2011).

\section{Gel Spreadability Test}

Spreadability measurement is carried out by weighing 1 gram of gel and then placed in the middle of a scaled round plate. On the top of the gel, another round glass is placed and given load so that the weight of round glass and load is 125 grams, then left for 1 minute. The spreadability of $5-7 \mathrm{~cm}$ shows a semisolid consistency which is very comfortable in application (Garg et al., 2002).

\section{Gel Adhesiveness Test}

0.25 grams of gel is placed between 2 object glasses, then pressed with $1 \mathrm{~kg}$ of load for 5 minutes. Then, the load is lifted from the object glass, then the object glass is installed on the 
Table II. Settings on Rheosys Merlin VR

\begin{tabular}{cc}
\hline Settings & Criteria \\
\hline Measuring system & Parallel plate \\
Equilibrium pre-sheer & 30 sec \\
Temperature & $25^{\circ} \mathrm{C}$ \\
Start Speed & $0,1 \mathrm{RPM}$ \\
End Speed & $300 \mathrm{RPM}$ \\
Number steps & $6 \mathrm{steps}$ \\
Delay time & $30 \mathrm{sec}$ \\
Integration time & $10 \mathrm{sec}$ \\
Direction & Up \\
\hline
\end{tabular}

adhesiveness test equipment. The test equipment was given a load of 80 grams and then the gel release time from the objects glass was recorded (Miranti, 2009).

\section{Gel Viscosity Test}

Gel viscosity was measured using Rheosys Merlin VR viscometer with $5 / 30 \mathrm{~mm}$ parallel plate spindle. The gel is placed on a plate and pressed with the parallel. The measurement parameters are arranged to be exactly the same so that all formulas got the same treatment, then run through a computer with Rheosys Micra application. The result of viscosity and rheogram profile measurement will come out of the screen and one of the rheogram profiles was taken as a reference for the viscosity value. Previously, test parameters have been set in the application (Table II). The selection of 6 steps shows the distribution of RPM elapsed, that is 0.1-60-120-18-240-300 RPM. The selection of this setting is based on the orientation that produces a stable thixotropic plastic rheogram. The results obtained is a viscosity value at 60 RPM (Prastianto, 2016).

\section{Data Analysis}

The optimization of the binahong leaf water fraction gel formula was carried out using Design Expert 11 Simplex Lattice Design method. Formula optimization was carried out by including independent variables of sodium alginate and carboxymethyl chitosan concentrations in the range of $0-3(\% \mathrm{w} / \mathrm{w})$ respectively. The data included as response variables include $\mathrm{pH}$, adhesiveness, spreadability, and viscosity. The optimal formula obtained is in the form of a comparison of certain concentrations of base combinations that can produce optimum physical properties in the binahong leaf fraction gel formula resulting from software prediction. Then the optimal formula from Design Expert 11 software prediction is validated to find out whether the results of the Simplex Lattice Design (SLD) model is valid or not. Validation is done by comparing the SLD prediction formula with the actual formula done by the researcher, then analyzed using the SPSS one sample t-test program with a confidence level of $95 \%$. From the calculation, whether there are significant difference in the response of the prediction and the experiment or not will be observed, so the conclusion whether the equation obtained from the program is valid (reliable) or not can be obtained.

\section{RESULTS AND DISCUSSION}

The development of binahong leaf water fraction in gel preparation form is considered according to the application of diabetes mellitus wounds treatment generally is wet wounds and requires preparation that is easily absorbed so that the appearance of preparation when applied looks good. In addition, the polar leaf fraction is suitable to be used on a polar basis, namely gel. The varied concentration range of gelling agent sodium alginate and carboxymethyl chitosan was chosen from $0-3 \%$ based on the orientation that sodium alginate on $3 \%$ concentration produced a thick gel. In this study, the concentration of sodium alginate and carboxymethyl chitosan was carried out in order to find the best concentration of both gelling agents, whether the single form was better than the mixed form which could affect the physical properties of the gel produced. The components needed in the formulation process are binahong leaf water fraction as active substance, sodium alginate and carboxymethyl chitosan with concentration variations as gelling agents, methyl paraben and propyl paraben as preservatives, glycerin as emollient, propylene glycol as a humectant, and distilled water as a solvent.

The results of organoleptic observations to the gel containing the fraction varied from slightly thick to very thick with light to dark brown color. The color comes from the color of binahong leaf water fraction dry powder. The formula containing more carboxymethyl chitosan components, gives a 


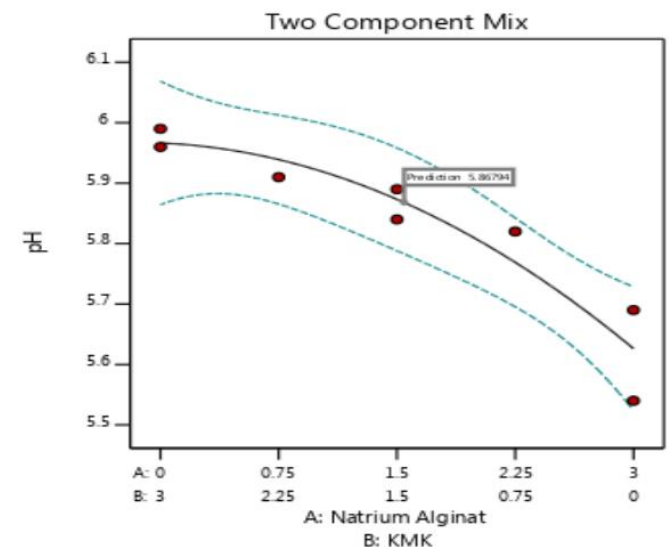

Figure 1. Relationship between sodium alginate and carboxymethyl chitosan to $\mathrm{pH}$ response

Table III. Organoleptic Test Results and pH Gel Binahong Leaf Water Fraction

\begin{tabular}{ccccc}
\hline Formula & Form & Color & Color Intensity & Odor \\
\hline F1 & Slightly thick & Dark brown & ++++ & Typical extract \\
F2 & Slightly thick & Dark brown & ++++ & Typical extract \\
F3 & Slightly thick & Dark brown & +++ & Typical extract \\
F4 & Quite thick & Light brown & ++ & Typical extract \\
F5 & Quite thick & Light brown & ++ & Typical extract \\
F6 & Thick & Light brown & ++ & Typical extract \\
F7 & Very thick & Light brown & + & Typical extract \\
F8 & Very thick & Light brown & + & Typical extract \\
\hline
\end{tabular}

Reference: $+=$ Faded; $++=$ Less thick; $+++=$ Thick; $++++=$ Very thick

darker brown color, while the formula containing more sodium alginate components will produce a more faded color. The formula with more amount of sodium alginate gives greater thickness compared to the addition of carboxymethyl chitosan. In addition, the gel has a distinctive smell from binahong leaf water fraction powder (Table III).

The $\mathrm{pH}$ value of binahong leaf water fraction gel (Figure 1) all meets the skin pH requirements (4.5-6.5), therefore able to prevent skin irritation. An alkaline gel can make the skin dry and cracked, and acidic gel can irritate the skin and causes reddish rash (Mappa et al., 2013). All the data of the $\mathrm{pH}$ test results were analyzed using the Design Expert 11 application to obtain the SLD equation and graph presented in Equation (1) and Figure 1.

$\mathrm{pH}=5.63 \mathrm{~A}+5.97 \mathrm{~B}+0.3075 \mathrm{AB}$.

Reference: $\mathrm{A}=$ Sodium alginate; $\mathrm{B}=$ Carboxymethyl chitosan; $\mathrm{AB}=$ Combination of sodium alginate and carboxymethyl chitosan

Analysis with the Design Expert 11 program on $\mathrm{pH}$ gel data gives a probability value $>\mathrm{F}$ value less than 0.05 , that is 0.0039 ; so that the resulting model is significant. The lack of fit value produced is not significant, indicated by the probability value $>\mathrm{F}$ value is more than 0.05 , that is 0.6687 , which indicates that the dispersion of $\mathrm{pH}$ gel data is even and the model is in accordance with existing data. Equation (1) shows that the $\mathrm{pH}$ response of gel dosage of binahong leaf water fraction is influenced by the components of sodium alginate, carboxymethyl chitosan, and a slight by the mixture of both, and all the three have a positive coefficient or positive effect. The carboxymethyl chitosan component plays a more dominant role in increasing $\mathrm{pH}$ response with the coefficient value of 5.97 compared to sodium alginate with value of 5.63. The graph (Figure 1) also shows that the increase in sodium alginate concentration accompanied by the decrease in carboxymethyl chitosan concentration will reduce $\mathrm{pH}$ response. This is caused by lower $\mathrm{pH}$ of sodium alginate compared to carboxymethyl chitosan. Sodium alginate has a pH of 7.2 (Rowe et al., 2009) and carboxymethyl chitosan has a $\mathrm{pH}$ of 7-9 (Kalliola et al., 2017). The interaction coefficient value of both in Equation (1) is 0.3075 . This shows that the interaction of those two components has little effect in increasing $\mathrm{pH}$. 


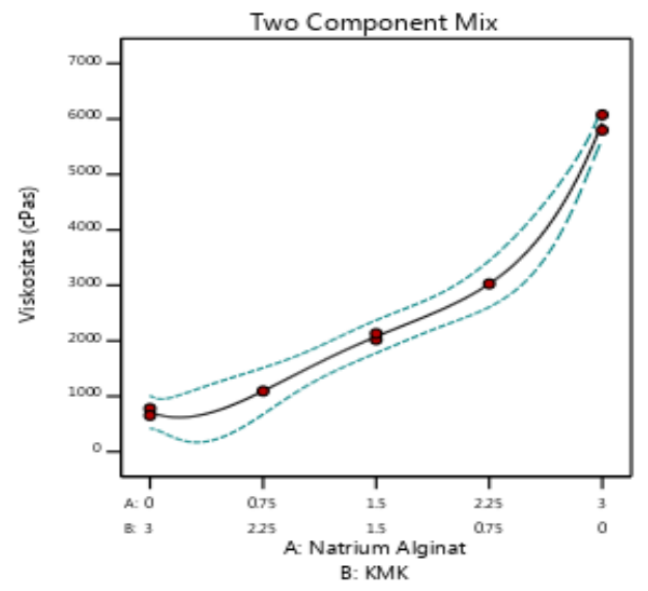

Figure 2. Relationship between sodium alginate and carboxymethyl chitosan to viscosity response

From the results of the study, the effect of sodium alginate and carboxymethyl chitosan or their interactions on viscosity response is reflected in the SLD equation (2) and Figure 2.

Viscosity $=5833.99 \mathrm{~A}+765.23 \mathrm{~B}-5514.94 \mathrm{AB}$

Reference: $\mathrm{A}$ = Sodium alginate; $\mathrm{B}=$ Carboxymethyl chitosan; $\mathrm{AB}=$ Combination of sodium alginate and carboxymethyl chitosan

Analysis with the Design Expert 11 program on gel viscosity data gives a probability value $>\mathrm{F}$ value less than 0.05 , that is 0.0001 ; so that the resulting model is significant. The lack of fit value that is produced significantly is indicated by the probability value $>\mathrm{F}$ value is less than 0.05 which is 0.0485 , which indicates that the model does not match the existing data and the model cannot predict well. Equation (2) above shows that the gel viscosity of binahong leaf water fraction is influenced by the sodium alginate and carboxymethyl chitosan components. Based on this equation, the sodium alginate component is more dominant in increasing the viscosity response with a value of 5833.99 compared to the component of carboxymethyl chitosan which has a lower coefficient value of 765.2. This is in line with the graph (Figure 2) which illustrates the increase in the concentration of sodium alginate and a decrease in the carboxymethyl chitosan concentration can increase viscosity response. This is because sodium alginate can form a thick colloidal dispersion (Rowe et al., 2009) so that it produces more gel with higher viscosity than carboxymethyl chitosan. The interaction of both affects the decrease in viscosity because the interaction coefficient value is - 5514.94. The negative value indicates that the use of combination will cause a decrease in gel viscosity caused by interactions between the two. Increasing amount of sodium alginate will increase the viscosity response while increasing the carboxymethyl chitosan level will reduce the viscosity of the gel preparation. The combination of the two will help each other in decreasing the viscosity of the gel response.

Spreadability tests have been conducted in order to determine the spreadability of the gel on the skin surface. The greater the spreadability, the easier it is to be applied topically and to optimize absorption on the skin. From the results of the experiment, the effect of sodium alginate and carboxymethyl chitosan or the interaction of both of them on spreadability responses is contained in the SLD equation (3) and Figure 3.

Gel spreadability $=13,76 \mathrm{~A}+25,96 \mathrm{~B}-9,18 \mathrm{AB}$

Reference: $A$ = Sodium alginate; $B$ = Carboxymethyl chitosan; $\mathrm{AB}=$ Combination of sodium alginate and carboxymethyl chitosan

Analysis with the Design Expert 11 program on gel spreadability data gives a probability value> $F$ value less than 0.05 , that is 0.0008 ; so that the resulting model is significant. The lack of fit value that is produced significantly is indicated by the probability value $>\mathrm{F}$ value is less than 0.05 , which is 0.0440 , which indicates that the model does not match the existing data and the model cannot predict well. Equation (3) above shows the spread of gel containing binahong leaf water fraction influenced by the component of sodium alginate, carboxymethyl chitosan and a mixture of both. The component of sodium alginate and carboxymethyl chitosan has a positive coefficient value which means that it has a positive effect on increasing spreadability. Carboxymethyl chitosan is more dominant in increasing spreadability, as evidenced 
Table IV. Weight Value Determination of Binahong Leaf Water Fraction Gel

\begin{tabular}{lcccc}
\hline \multicolumn{1}{c}{ Parameter } & Goal & Lower & Upper & Importance \\
\hline $\mathrm{pH}$ & In range & 4.5 & 6.5 & +++ \\
Viscosity & In range & 2000 & 4000 & +++++ \\
Spreadability $\left(\mathrm{cm}^{2}\right)$ & In range & 19.62 & 38.46 & +++ \\
Adhesiveness (seconds) & Minimize & 2 & 300 & +++ \\
\hline
\end{tabular}

Reference: $(+)$ dan $(++)$ = low priority; $(+++)$ dan $(++++)=$ middle priority; $(+++++)$ = high priority

Table V. Validation of Optimal Formula from Software Prediction against Actual Result

\begin{tabular}{lcccc}
\hline \multicolumn{1}{c}{ Parameter } & $\begin{array}{c}\text { Program } \\
\text { Prediction }\end{array}$ & $\begin{array}{c}\text { Experiment } \\
\text { Results }\end{array}$ & Sig (2 tailed) & Ref: \\
\hline $\mathrm{pH}$ & 5.87 & 5.88 & 0.513 & + \\
Viscosity & 2000 & 2267.71 & 0.084 & + \\
Spreadability $\left(\mathrm{cm}^{2}\right)$ & 21.96 & 20.95 & 0.098 & + \\
Adhesiveness (seconds) & 19.82 & 21.50 & 0.409 & + \\
\hline
\end{tabular}

Reference: $(+)$ = not significantly different; $(-)$ = significantly different

by its coefficient value of 25.96 , while sodium alginate is only 13.76 . The interaction of the two influences increases the spreadability because it has a positive coefficient value, which is 9.18. From the graph (Figure 3) shows that an increase in the concentration of sodium alginate followed by a decrease in carboxymethyl chitosan concentration can reduce the gel response spreadability of the binahong leaf water fraction. Conversely, an increase in carboxymethyl chitosan concentration with a decrease in sodium alginate concentration can increase the spreadability of gel.

Adhesiveness test aims to determine the ability of the gel to stick to the skin, with the aim of optimizing therapy. From the results of the experiment, the effect of sodium alginate and carboxymethyl chitosan or the interaction of both of them on the adhesiveness response is contained in the SLD equation (4) and Figure 4.

Gel adhesiveness $=79,28 \mathrm{~A}+2,68 \mathrm{~B}-89,45 \mathrm{AB}$

Reference: $\mathrm{A}$ = Sodium alginate; $\mathrm{B}=$ Carboxymethyl chitosan; $\mathrm{AB}=$ Combination of sodium alginate and carboxymethyl chitosan

Analysis with the Design Expert 11 program on gel adhesiveness data gives a probability value> $F$ value less than 0.05 , which is 0.0004 ; so that the resulting model is significant. The lack of fit value produced is not significant, indicated by the probability value $>\mathrm{F}$ value is more than 0.05 , that is 0.7568 , which indicates that the dispersion of gel adhesiveness data is even and the model is in accordance with existing data. Equation (4) shows that the adhesiveness of gel preparation of binahong leaf water fraction is influenced by the component of sodium alginate and carboxymethyl chitosan component. Based on this equation, the sodium alginate component is more dominant in increasing the adhesiveness response (coefficient value 79.28) compared to the component of carboxymethyl chitosan which has a lower coefficient value of 2.68. The interaction of both affects the decrease in adhesiveness because the interaction coefficient value is -89.45 . The negative value indicates that the use of combination will cause a decrease in gel adhesiveness caused by interactions between the two. From the graph (Figure 4) shows that an increase in the concentration of sodium alginate followed by a decrease in carboxymethyl chitosan concentration can reduce the gel adhesiveness response of the binahong leaf water fraction. These results are in accordance with the results of the spreadability test previously discussed, that the value of adhesiveness is inversely proportional to the spreadability. In addition, the value of adhesiveness is also related to the results of viscosity, namely an increase in viscosity accompanied by an increase in the value of adhesiveness.

Optimization of the gel formula from binahong leaf water fraction was carried out by using Design Expert version 11 using Simplex Lattice Design method. The test results of gel physical properties parameters such as $\mathrm{pH}$, viscosity, spreadability, and adhesiveness were analyzed using the program to produce a mixed two-component graph. To produce the graph, a goal is determined in the form of desired range, minimize, and maximize for each parameter 


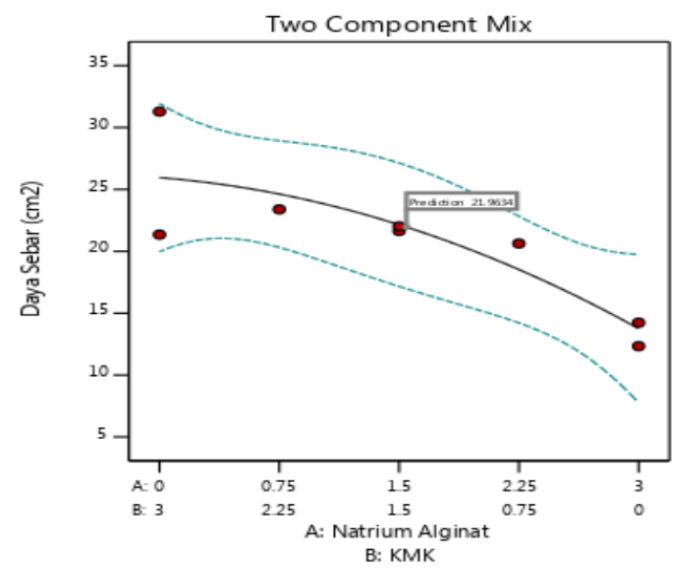

Figure 3. Relationship between sodium alginate and carboxymethyl chitosan to spreadability response

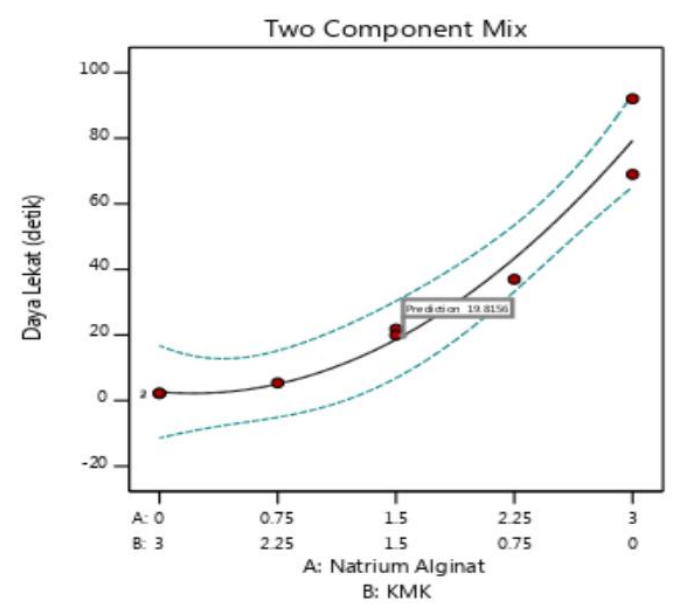

Figure 4. Relationship between sodium alginate and carboxymethyl chitosan to adhesiveness response

(Table IV). Weighting and determining the lowest and highest values (Table IV) are set based on the terms specified by the literature. Sodium alginate and carboxymethyl chitosan as factors that influence the physical response of the gel selected in range $0-3 \%$. The $\mathrm{pH}$ response is chosen in a range from 4.5-6.5 considering that the $\mathrm{pH}$ value of the gel preparation in topical use must be in accordance with the $\mathrm{pH}$ of the skin. Spreadability response is selected in range with the consideration that the desired spreadability is only a formula with a spreadability area of 19.62-38.46 $\mathrm{cm}^{2}$. Selecting the range to obtain a gel that is comfortable to use. The adhesiveness response of minimize was selected because the results of measurements of the experimental adhesiveness were high that it would affect the spreadability and viscosity. Therefore, a minimum value is chosen but still produces a gel that is comfortable to use. The viscosity response in range was chosen considering the gel with a base carboxymethyl chitosan had a low viscosity of less than $2000 \mathrm{cps}$, while the base of sodium alginate had a viscosity value of more than $4000 \mathrm{cps}$. The good viscosity value is 2000-4000 cps (Garg et al., 2002). Therefore, a formula that has good viscosity and in a good viscosity range is obtained so that the gel is not too liquid and not too thick that it is comfortable to use. Viscosity has the highest degree of importance $(+++++)$ because viscosity is a very important parameter that can affect spreadability and adhesiveness. The viscosity must be suitable, should not be too high or low so that the viscosity is considered important in obtaining gel preparations that meet good gel requirements.

After all data is filled in, the Design Expert program will present a two components graph of the mixture between sodium alginate and carboxymethyl chitosan. The program then chooses one formula that is considered to have the highest desirability, so the selected optimum formula will produce good physical properties for the gel. The contour graph of gel formula plot of the binahong leaf water fraction is presented in Figure 


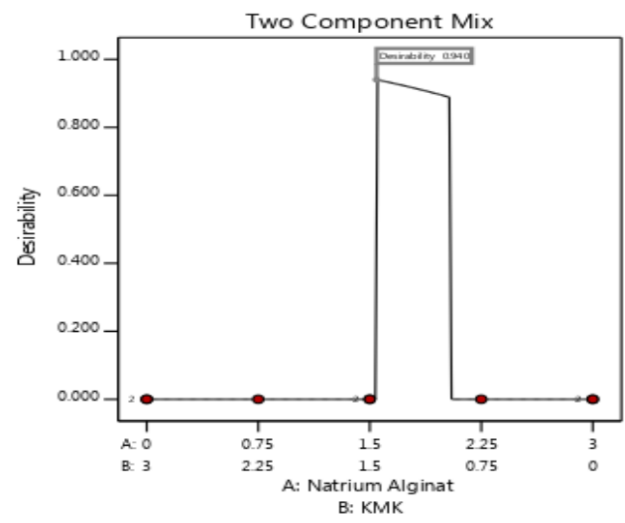

Figure 5. Optimal formula prediction graph on binahong leaf water fraction gel

5. In Figure 5, the optimal point of sodium alginate and carboxymethyl chitosan combinations is indicated by a box with desirability of 0.940 . The concentration ratio of gelling agent to produce the optimal formula is sodium alginate $1.546 \% \mathrm{w} / \mathrm{w}$ or 1.546 grams in 100 grams of carboxymethyl chitosan formula and $1.454 \%$ or 1.454 grams in 100 grams. The response value of the gel physical properties in binahong leaf water fraction from the optimal formula was also obtained from Design Expert prediction using Simplex Lattice Design method (Table VI).

The results of the response prediction $\mathrm{pH}$, viscosity, spreadability, and adhesiveness then compared with actual results response on the verification stage. The optimal formula verification is a step taken to find out whether the predicted value obtained is in accordance with the actual value. One sample t-test analysis was used to determine whether there were significant differences between predicted parameter values and experimental results (Table V). Data from the analysis (Table $\mathrm{V}$ ) shows that there is no significant difference between predicted parameter values and experimental results (sign $<0.05$ ), so it can be concluded that the Simplex Lattice Design equation developed can be used to formulate a gel formula validly.

\section{CONCLUSION}

The results of the gel formula optimization from the binahong leaf water fraction using the Simplex Lattice Design method showed that the combination of gelling agent sodium alginate $1.546 \%$ and carboxymethyl chitosan $1.454 \%$ produced a gel that met good physical requirements. The combination of sodium alginate and carboxymethyl chitosan increased the response of $\mathrm{pH}$ and spreadability and reduced the viscosity and gel adhesiveness of the binahong leaf water fraction. The prediction results of Simplex
Lattice Design is valid with optimal formula for response value of the physical parameters $\mathrm{pH}$ 5.86; viscosity of $2000 \mathrm{cps}$; spreadability of $21.96 \mathrm{~cm}^{2}$; and adhesiveness of 19.81 seconds.

\section{REFERENCES}

Eriadi, A., Arifin, H., Rizal, Z., Barmitoni, 2015, 'Pengaruh Ekstrak Etanol Daun Binahong (Anredera cordifolia (Tenore) Steen) Terhadap Penyembuhan Luka Sayat Pada Tikus Putih Jantan', Jurnal Farmasi Higea, 7(2), 163-173.

Garg, A., Aggarwal, D., Garg, S., Singla, A.K., 2002, 'Spreading of Semisolid Formulation: An Update', Pharmaceutical Technology, 84-105.

Kalliola, S., Repo, E., Srivastava, V., Heiskanen, J.P., Sirvio, J.A., Liimatainen, H., Sillanpaa, M., 2017, 'The $\mathrm{pH}$ sensitive properties of carboxymethyl chitosan nanoparticles cross-linked with calcium ions', Colloids and Surfaces B: Biointerfaces, 153, 229-235.

Kartika, R., Gadri, A., Darma, E., 2015, 'Formulasi Basis Sediaan Pembalut Luka Hydrogel dengan Teknik Beku Leleh Menggunakan Polimer Kappa Karagenan', Prosiding Penelitian Sivitas Akademika Unisba, 643-648.

Laissa, U., Wulan, A.J., Prabowo, A.Y., 2017, 'Pengaruh Binahong terhadap Luka Bakar Derajat II', Majority, 7(1), 130134.

Lund W, 2009, The Pharmaceutical Codex Principles and Practice of Pharmaceutics, 12th ed, CBS Publisher, London.

Mahanani, R. M. A. P., 2009, Efek Penambahan Berbagai Peningkat Penetrasi Terhadap Penetrasi Perkutan Gel Natrium Diklofenak Secara In Vitro, Skripsi, Fakultas 
Farmasi, Universitas Muhammadiyah Surakarta, Surakarta.

Mappa, T., Edy, H.J., Kojong, N., 2013, 'Formulasi Gel Ekstrak Daun Sasaladahan (Peperomia pellucida (L.)H.B.K) dan Uji Efektivitasnya terhadap Luka Bakar pada Kelinci (Oryctolagus Cuniculus)', Jurnal Ilmiah Farmasi-UNSRAT, 2(2).

Miranti, L., 2009, Pengaruh Konsentrasi Minyak Atsiri Kencur (Kaempferia galangan) dengan Basis Salep larut Air terhadap Sifat Fisik Salep dan Daya Hambat Bakteri Staphylococus aureus secara In Vitro, Skripsi, Fakultas Farmasi Universitas Muhamadiyah, Surakarta.

Prastianto, B.A., Optimasi Gelling Agent Carbopol 940 dan Humektan Sorbitol dalam Formulasi Sediaan Gel Ekstrak Etanol Daun Binahong (Anredera cordifolia (Ten.) Steenis), Skripsi, Universitas Sanata Dharma, Yogyakarta.

Rowe, R.C., Sheskey, P.J. dan Owen, S.C., 2009, Handbook of
Pharmaceutical
Excipients, 6th ed, Pharmaceutical Press and American Pharmacist Assosiation, London.

Shanti, W. N., dan Mita, S.R.M., 2011, Formulasi Sediaan Masker gel Antioksidan Dari Ekstrak Etanol Biji Belinjo, Skripsi, Fakultas Farmasi, Universitas Padjajaran, Bandung.

Sinko, P.J., 2011, Martin's Physical Pharmacy and Pharmaceutical Sciences, Lippincott Williams \& Wilkins, Philhdelphia, 469-471.

Swastika, A., Mufrod, dan Purwanto, 2013, 'Aktivitas Antioksidan Krim Ekstrak Sari Tomat (Solanum lycopersicum L .)', Trad. Med. J., 18, 132-140.

Vivian-Smith, G., Lawson, B,E., Turnbull, I., Downey, P.O., 2007, 'The Biology of Autralian Weeds 46 Anredera cordifolia (Ten.) Steenis', Plant Protection Quarterly, 22(1), 2-20.

Xue, X., Li, L., dan He, J., 2009, 'The Performance of Carboxymethyl Chitosan in Wash-off Reactive Dyeings', Carbohydrate Polymer, 75, 203-207. 